\title{
'I want to be a TV historian when I grow up!'1 \\ On Being a Rewind Historian
}

\author{
MICHELLE ARROW
}

Public History ReVIEW, VOL 12, 2006, PP80-91

$t$ all started with a screen test. Well, actually, it started a little earlier than that.

I got a call from a guy at the Australian Broadcasting Commission (ABC) who

told me that they were talking to people about producing a history series and could I please come in for a chat? So I went in for the meeting, which was filmed. This was round one, and I made it through. I was then asked to come back for a 'proper' screen test. This consisted of spending an hour in hair and makeup and talking in front of a camera again - but this time, I had to talk to the camera - 'like it's your friend', they told me. Well, talking to the camera like it's your friend is all very well but I wasn't allowed to furrow my brow, use my hands or do any of the things I might normally do in conversation.

By this stage the whole experience was feeling a little like Historian Idol. But I finally got through to the third round. This was the big scary one. We all had to go to Circular Quay in Sydney harbour on a sunny mid-week afternoon amid curious crowds and buskers to talk about the 'first night the first fleet were in Sydney Harbour' for about five minutes. Being a historian of the twentieth century, not actually knowing a whole lot about the first night the first fleet was in Sydney Harbour, and thinking that the whole thing sounded a bit Eurocentric and old-hat anyway, I had to do a lot of hurried research. But after speaking s-I-o-w-I-y to camera I was told that my carefully crafted little story about the encounter between Indigenous Australians and Europeans in Sydney Cove was 'a little bit who cares?'

It was a bruising start, and in some ways, a bit of a portent of things to come. But nonetheless, I weatherd the auditions and was hired to start in late in 2004. Being a 'television historian' wasn't something I dreamed of being when I grew up. But having done just that for the past nine months has been an extraordinary experience - equally enriching and difficult. We worked on the program from January 2004 and the show finished its fifteen-program run in early November 2004. The ratings have been respectable - as good as could be expected when 
you're running at $9.25 \mathrm{pm}$ on Sunday nights. We showed that there was an (albeit select) audience out there for Australian history on television in a magazine-style format. This did not, however, stop the powers that be at the $A B C$ from axing the show, yet another decision which seems set to keep Australian history from regularly appearing on our television screens for some time.

The politics of the $A B C$ are a minefield I have no intention of blundering into here. Instead, I would like to explore some of the issues that one faces as a 'television historian'. Were we, the historian-presenters, just 'meat puppets', as the crew sometimes refer to on-camera talent, parroting the words of our producers? How much control were we able to exert over our role and presence in the storytelling process? To do this, I would first like to look at the qualities of television history: what are its flaws and virtues? How is it different from written history? I will then look at recent history on television to consider the media context in which Rewind was made and received. I would then like to consider the role of historians, including myself and my fellow historian-presenters, in the making of Rewind and close with some reflections on the process.

The recent Australians and the Past survey suggested that television - and film - is where the majority of the population gains their knowledge about the past. When respondents were asked about historical activities they had participated in over the past twelve months, eighty-four per cent said they had watched movies or television. Only the activity of viewing photos rated higher. ${ }^{2}$ History on television offers the promise of immediacy, connection and emotional heft. Through its combination of personal stories, archival footage and narrative drive, at its best, television history has a visceral power that few texts can match. As David Cannadine notes, 'TV can convey the immediacy of historic events with unrivalled and overpowering vividness. ${ }^{3}$ This is both its great strength and its great weakness because, as Cannadine adds, television is 'rarely so good at providing context of analysis or perspective or proportion.' 4 Television works best, we are told, when it centres on a narrative with few characters, a driving central issue and a resolution of sorts. A further characteristic of television is that it is visual, not verbal. To make television you must think in images rather than words, and in few words at that. Most of my attempts at television script writing were harshly critiqued as 'too wordy'. Every adjective was questioned. Every word scrutinised. Detail tends to be the first casualty of television scripts particularly when you're telling large stories in a fifteen-minute segment. It's a relentless process of paring down, of sacrificing good 'grabs' for the sake of the narrative line.

Television's reliance on images means that feeding the beast with pictures is a relentless process. Too many photographs are never enough and archival footage is precious. Many potential stories for Rewind were thrown out at the early stages because there 'weren't enough pictures', meaning footage, which limited our options somewhat. The archival record tends to determine your subject matter: something has to have been deemed newsworthy in the first place for footage to exist, which has serious implications if you want to tell hidden 
histories about things such as the secret armies of the 1930s or of contraception. Archival footage also comes from the archives that have already constructed and interpreted the events it depicts. If you don't have pictures, you have few options. You can shoot 'guilty buildings', the places where historical events took place, and hope that evocative voiceover will get you through. Or you can shoot reenactments, which are often costly and can run the risk of cheesiness. The other storytelling tool used in television history that has returned to favour in the past ten years or so is the presenter, a development that I will return to later.

All of these qualities mean that while history on television might have emotional impact it can also be superficial, misleading or downright incorrect. But historical television is popular: even a poorly-rating episode of Rewind might have had 400000 viewers. Academic historians can only dream of audiences like these for their books. The popularity of television history is just one of the reasons academics are uneasy with it. Simon Schama suspects that academics dislike television history because they feel that 'the subtlety of history is too elusive, too fine and slippery to be caught in television's big, hammy fist; that try as it might, television can't help but simplify the complications; personalise the abstract; sentimentalise the ideological and just forget about the deep structures. ${ }^{5}$ Television history tends to prefer the narrative over the analytical. History on television is presented as a tale of 'what happened' rather than asking how we know what happened. As Natalie Zemon Davis pondered, there is no room in film or television for the 'perhapses and the maybes' so beloved by academic historians. ${ }^{6}$ Historian lan Jarvie pleaded: 'when will we get a... series that yet acknowledges that we cannot explain everything and that controversy about just what happened and why is worth airing?'7 An approach that might question sources, demonstrate processes and present numerous competing accounts of the past is rare. Cannadine acknowledges that, on this score, television history has fallen out of step with academic history: 'much of the most exciting work being undertaken by historians today tries to present many voices and different viewpoints; but as written and presented, media history is still largely confined to linear narrative. ${ }^{, 8}$

There was a general feeling in the Rewind offices that multiple interpretations would be confusing; that what the audience wants to know is what $I$, the historian, thought on a particular issue or person. Was Breaker Morant a scapegoat or scoundrel? Was Sister Elizabeth Kenny a charlatan or a messiah? These dilemmas seemed horribly reductive to me and I resisted them. But perhaps that is what people want: one of my students came and asked me recently: 'because my mum wants to know, do you think Breaker Morant was guilty or innocent?' While the academy might resent such simple questions as being unreflective of our work, as an approach to television history it often worked well - it provided a clear narrative structure and drew stories to a natural conclusion. But it also posed problems.

Yet the problems faced by the makers of television history are very similar to the problems faced by academic historians. How do we construct a narrative (of 
sorts) from a mass of archival and secondary material? How do we place this narrative in its appropriate historical context? How do we deal with the gaps in the historical record? How do we go about extracting meaning in manageable amounts from unruly, obtuse or prolix interviewees (both eyewitnesses and historians)? How do we interpret the elusive source? How can we give voices or agency in our histories to those who left no records? How do we interpret media representations of the past? All of these are problems I have been faced with writing academic history but also in producing television history, although in writing academic history I never had to worry about blow-drying my hair and checking my lippy. Perhaps the main divergence between television and academic history is the importance of images. This is a huge difference and it means that historians and television producers are often speaking different languages.

Historians, as Sue Castrique notes, are slowly becoming more adept in the use of images but academic history is still produced in largely written form. ${ }^{9}$ The use of television as a source for history, rather than as a subject for history, is still unusual, so historian's unease with television is not entirely unexpected. But television's visuality can offer us a tangible, visible connection with the past. For example, in the Rewind story on Jandamurra, the famed figure of Aboriginal resistance in the Kimberley, seeing his breathtakingly beautiful country can tell us a great deal about him, and his struggle, than the same scene described on the page. In this respect, television history has an edge over written history. An image can convey an impressive amount of detail in seconds, and in 'the detail of dress, uniform, facial expression and attitude, can help give understanding to an event in a completely different way to that of a dozen documents. ${ }^{10}$ Yet perhaps images are less subject to questions of bias and interpretation and tend to be accepted as 'fact' without considering the reason the film was produced in the first place.

The problems of television nothwithstanding, television history is on the rise. In recent years, television history has been called 'the new rock and roll', the 'new gardening', and even, by Dawn Airey, the former Chief Executive of Channel 5, 'the new sex. ${ }^{11}$ We have certainly been watching a lot of British and American television history lately. There have been the forensic history series such as Crime Team and the original model for Rewind, the American PBS series History Detectives which teamed a group of historians and antiquarians to trace the provenance of various objects. One episode unravelled the truth behind a collection of bullets owned by a woman whose father told her they came from the bodies of Bonnie and Clyde. While these programs tapped into the apparently unquenchable thirst for crime on television their main drawback was that they tended to reduce history to a series of artifacts in search of a story. So we found out that the bullets probably didn't come from Bonnie and Clyde's bodies but we were left with no greater sense of the cultural significance of these Depressionera outlaws. It runs the risk of being little more than current affairs in period costume. 
We've also seen the rise of so-called 'living history' shows such as The 1940s House, Edwardian Country House and Regency House Party. All follow the reality TV formula of placing people in an isolated environment and watching them squirm under extreme conditions - the sort of manufactured human drama that has made programs like Survivor and Big Brother so addictive. Another kind of 'reality' television was the SBS series Home Made Histories which comprised short compilations of people's Super-8 home movies with narration provided by the creator of the films. We have also seen the reenactment return to television history, especially in the various Richard Starkey series on the British monarchy, and it is used in an increasingly sophisticated and self-conscious way in the recent Seven Wonders of the Industrial World where long-dead historical actors were 'interviewed' on-screen. This was a playful solution to the problem of a lack of eyewitnesses or archival footage. Finally, television history is seeing a return to big narrative histories told by on-camera historian-presenters. ${ }^{12}$

Australian television has been dominated by these sorts of history programs as well as the more conventional obsession with Ancient Egypt, wars and Nazis which forms the bulk of programming on the History Channel. Even the ABC's traditional history timeslot $-7.30 \mathrm{pm}$ Sunday nights - has been dominated by histories other than our own. Australian history television has ranged from the nostalgic popular history presentations of Peter Luck, such as This Fabulous Century made in the 1970s to the successful series and mini-series such as The Sullivans, Anzacs, Bodyline, Vietnam and The Dismissal which have arguably done a better job at putting aspects of Australia's social history on screen than any historical documentary. The $A B C$ made a bold foray into the history of race relations with the landmark series Frontier and after a few years of shying away from making big television histories of the nation - such as Federation and 100 Years - we are seeing a return to history in the newer overseas formats. Both the ABC and SBS are trying 'reality' shows - The 1860s House and The Colony respectively - which were in production in October-November 2004. The ABC has also ventured into the 'nostalgia' genre with its appeals to audience identification and shared memories of popular culture in shows such as The Way We Were and even Mondo Thingo.

This leads us to Rewind, a weekly magazine series that presents a range of stories from Australia's past. The ABC produced this show as part of a special initiative to produce Australian history for television, in accordance with its charter obligations. In many respects, it is remarkable that there has been so little Australian history on our screens recently. Australia has a big potential market for history. Popular histories of war always sell well in Australia and mass-market historical fiction is extremely popular. Historian and former ABC program maker Tony Moore contemplated this in the Sydney Morning Herald a few months ago. He argued that the fact that our television programmers choose instead to program British and American historical documentaries instead of Australian history reflected a 'deep colonial cringe in our programmers. ${ }^{13}$ Related to this, I suspect, is the fact that Australian history is rarely told on television in the big, 
expensive ways that British and American TV history has been. Our television executives seem to be in thrall of the modes of British and American TV history rather than the histories themselves. Australian historical television is unlikely to find many buyers overseas which compounds the problem of cost for Australian programs. But Moore also suggests that part of the reason that Australian television has neglected Australian history is 'the wrongheaded belief by TV executives that Australian history is boring.' Certainly the idea that Australia had a 'small' history was one I heard voiced by the very highest echelons of leadership at the ABC which continues to make Australian history on TV a tough sell.

So, into this charged environment I plunged, acutely aware of the potential pitfalls of television history and history on film. I approached the experience of Rewind with excitement and trepidation - excitement at the program's potential to bring large audiences to Australian history and trepidation about how this would be achieved. Would I be able to respect myself in the morning? The show had a 'troubled' gestation as anyone who reads media gossip columns and Crikey.com would know. ${ }^{14}$ There were leaks and gossip and for a while there the whole experience was like being in an episode of Frontline. But the final program was not that different to the original proposal - to present investigations into aspects of Australia's past. The presenter line-up consisted of three historians: host Michael Cathcart, Rebe Taylor and myself and four journalist-reporters - Peter George, Justin Murphy, Christopher Zinn and cartoonist Warren Brown. The stories are generally told as presenter-driven explorations, structured as a quest to answer a question. So how deeply were the historians involved in this storytelling process? Television history is deeply collaborative, the product of many voices, starting with the researchers who slogged away to find the stories for us to tell. Once they found the story they would compile a research brief which would then be handed onto a producer. Ideally, the producer and reporter would then collaborate on a shooting script, reading the research material and determining the way the story would be told. Filming for each story generally took about a week then we would transcribe and log everything, write a script and then go into editing and post-production. All up, this process can take more than six weeks for something that will be on air for no longer than fifteen minutes or so.

My role in all this varied according to who I worked with. Sometimes I had a high level of input. I worked, for example, with producer Rebecca Latham on three stories, and we developed a good working relationship and determined the intellectual and narrative line of stories together. I worked on one story that was based on some of my $\mathrm{PhD}$ research and that was largely driven by my own research questions. On other stories I became part of the process late and read enough research to do the interviews and write the pieces to camera. In this mode, the historian becomes a storytelling tool for the producer rather than the driving force behind the historical interpretation and narrative on-screen. Working collaboratively was one of the most delightful but most difficult parts of producing television. I have team-taught and written collaboratively in the past but television 
is a team game: you work with a range of people to produce your stories which means that the story is enriched by having lots of different input. But interesting ideas can sometimes be lost in the process as well. I had to learn very quickly to be flexible and to relinquish control. While I knew a lot about history I was reminded that I 'don't know about television', so my chances of involvement on that scale were diminished.

Related to the role of the historian in production is the way the historian is constructed in the program, the way their authority is constructed by, and used within, the program. In the new British history television, most of the presenters such as David Starkey, Simon Schama - are male, continuing a tradition of using male historians or male voiceovers for historical television supposedly because they are believed to add gravitas. The public image of an historian is still male and middle-aged, cemented and reinforced in the public consciousness by early television historians such as A.J.P. Taylor and Hugh Trevor-Roper or in Australia, Geoffrey Blainey or Manning Clark. On Rewind we had two youngish female historian presenters and four middle-aged men, one of whom is a historian. Predictably, there was more focus on the women's appearances than that of the men: we were given make-up lessons and wardrobes provided for us while the men did not. I was told that I needed to have my makeup and hair right so that people would listen to what I said.

In the Rewind stories, the historian-presenter acted as the proxy for the audience, guiding them through the records and archives - and the show does often show historian's research processes albeit in a glammed up and abbreviated way. Some of the stories are told in the first person to differentiate us from supposedly detached journalists, underpinned by the notion that historians look at the world with a particular, individual world view. We were encouraged to convey in the voiceover the idea that we were going on a journey of discovery rather than telling the audience the where, what and why from a position of Godlike authority. Certainly trying to do a piece to camera while riding a replica of a Lawrence Hargrave box kite in a skirt on the beach near Wollongong left me little room for gravitas but it did show a historian interacting with her environment, attempting to demonstrate that the kite could fly, just as its inventor, Lawrence Hargrave, had proved it could all those years ago. I don't think they would have asked an older man to do it but maybe the kite wouldn't have lifted an older man into the air either.

The use of presenters means that we were effectively presenting history as one person's (authoritative) account. British telly-don Simon Schama has no problem with this. He sees himself as part of a tradition of storytelling and performativity in history and notes that history's origins are oral rather than written. ${ }^{15}$ Downing argued that historian-presenters are 'the storytellers of our age. They are the ones who bring the research out of the academy and offer it to the many'. ${ }^{16}$ I wonder though whether a young woman would be accepted in Schama's role presenting a history of the nation? The narrator's authority is supported by the use of evidence. As lan Jarvie noted in his review of a television 
history, 'after all, the point the interviewee makes always coincides with that being made by the narration!' 17

The authority of the Rewind presenters was related to the program's stories but also to our publicity. Much was made in the initial press releases about the show that Michael, Rebe and I were historians. And I was given my 'Dr' title in the publicity material. In the program, we were always introduced as 'historian Michelle Arrow' or 'award-winning historian Rebe Taylor'. But the effect of this was somewhat diminished by referring to cartoonist Warren Brown as 'cartoonist and historian Warren Brown'. Presenting itself is a performance of historical authority and engagement: resting atop a pile of research and hard slog done by the team, your task is to tell the story, hopefully with a little analysis squeezed in, all with an economy of words and gestures. The presenter, particularly an inexperienced one, had to take direction like an actor - don't smile as much there, look more thoughtful here.

So much for the performance: how did the audience receive us? Comments on the Rewind guestbook hint at what some expect of their television 'historians'. One of the features of the magazine format of Rewind was the 'value added back announce' - a short chat between Michael and the presenter of the story usually designed to reveal an interesting anecdote that couldn't fit into the story, or to allow the presenter to give their perspective on the story. In discussing the Sister Kenny story, I mentioned the fact that Sister Kenny was buried with both the Australian and American flags on her coffin and I used this as a launching pad to discuss Sister Kenny's relationship with America (she became hugely famous and admired there in the 1940s). One viewer, however, was less than impressed with my historian's speculations, claiming: 'Another point to note is an historian using the words "I think" numerous times in an answer to a question, when a look at the facts as they present themselves would have been more accurate'. ${ }^{18}$ The audience was apparently less interested in interpretations than 'facts'. If we did offer an interpretation of events which, after all, is what historians do, we often provoked controversy. Viewer Sarah Masters wrote on the guestbook: 'The people involved with both of these stories set out to demonise both of them, thus not allowing the viewers to make an informed opinion. ${ }^{, 19}$ This 'just the facts, Ma'am' attitude was similar to the expectation I detected in the production office that historians should be intimately familiar with minute detail. When we did object to something that was factually incorrect - for example, I asked a producer to change his description of 1920s Sydney as an era of gangsters and speakeasies - we sometimes ran the risk of being labeled 'difficult'.

Rewind also relied on the co-operation of a large number of historians, who endured countless phone calls and strange requests. Yet our relationships with academic historians were somewhat fraught. Rewind didn't put a lot of academic historians on screen. Historians were described in the office as a bit passionless, a bit equivocal; they were accused of refusing to talk in sexy soundbites. This is a source of frustration for producers who sometimes felt that historians whose work was being used on television should be 'grateful' for the coverage. One producer 
I worked with was annoyed when a historian insisted on payment for an interview. But the person in question had just completed a PhD and did not have an ongoing academic position.

This sort of attitude hints at a source of the tension between television and the academy. Some scholars see involvement with the media as a fate worse than tutoring. To collaborate with producers and journalists is to sell out and dumb down; ${ }^{20}$ television will take your hard-earned research and cheapen it, milk it for its shock value, thrust you into a position where you have to speak in simplistic 'grabs'. Academic lan Kershaw notes that historians generally have no say in how their contributions are used which can make for some sleepless nights on both the part of the television historian and the historian who will end up on television. Kershaw points out that television needs academic historians to legitimate their programs, particularly for non-academic audiences. 'Ultimately', he notes, 'these producers need professional historians... more than the historians need television. ${ }^{21}$ Television producers rely on the work of academic historians for their stories because original historical research is extremely time consuming and expensive.

Television tends to greedily consume the work of academic historians and journalists and presents it as 'new' which, for most people, it is. In The History Wars Stuart Macintyre refers to the way that the discoveries of historians are never reported in the media in the way that discoveries of scientists are ${ }^{22}$ in accordance with the popular belief that history is 'out there', waiting simply to be written up rather than constructed. Rewind managed to get publicity for some of the 'scoops' in the stories we produced but they were presented as though we had made the discoveries ourselves rather than bringing the work of historians to a wider audience.

When Rewind presented a story that 'revealed' that Australia's Nobel Prizewinning scientist McFarlane Burnett had advocated germ warfare in the 1950s to counter 'a threatened invasion by overpopulated Asiatic countries', it was reported in the Sunday Telegraph ${ }^{23}$ and on the ABC news the day the story went to air. But historian Dr Phillip Dorling had made this discovery several years earlier though, to be fair, the story presented the information as his discovery and journey. But the idea that history lies out there, awaiting a chronicler, was also reflected in one reviewer's response to the show. He noted that the most interesting story was on the destruction of the career of Eugene Goosens in Sydney through his involvement in a pornography scandal. The story, produced by David Salter, contained a great deal of new, previously unseen material photographs and interviews related to the case - but the reviewer dismissed this act of historical construction and interpretation with the line 'interesting, but not new; a Google search turns up all the facts of the case. ${ }^{24}$ If only writing history were as simple as doing a Google search.

Rewind needed historians in front of and behind the camera. And they needed to invest us with sufficient stature to lend authority to the program. Closely yoked to the question of our authority as presenters was the issue of 
form: how were we presenting history on Rewind? To illustrate this, I want to touch on the process of making a story, taking as my example the Sister Kenny story that appeared in Episode five. Sister Elizabeth Kenny was a bush nurse from Queensland who came up with a controversial new treatment for polio, took it throughout Australia and then to the United States where she became famous and admired: a Hollywood biopic was made of her life. When I was reading about Sister Kenny, and watching the treacly biopic that stars Rosalind Russell and presents Sister Kenny's preferred version of her life story, I was constantly oscillating between thinking that she was amazing and that she was a manipulative fraud.

The nature of polio itself ${ }^{25}$ made it difficult to determine how useful Kenny's treatment actually was and it seemed to me more interesting to present that dilemma, present the evidence and let the audience make up their own minds, rather than saying: Sister Kenny, here's exactly what I think, end of story. I would rather present ambiguity and let the audience think a bit more. Of course, what I want in a history TV show is probably not what most of the audience wants. The sorts of historical documentaries I find most challenging and invigorating are the ones that experiment with form and narrative certainties which leave questions unanswered. I didn't expect that I would be making these sorts of programs on Rewind; it is difficult to get historiographically complex historical television onto our screens. I was working with people who were very experienced television producers. But because they were trained in television, not in history, they tended to reproduce the same sorts of presentations of television history that we're used to or to produce the same sorts of television they were used to making before they came to Rewind such as cooking shows or Australian Story. Producers are trained to tell emotionally engaging stories in a clear and intelligent way but there was a reluctance to stray too far from the parameters of the known television universe.

Perhaps this is also one of the pitfalls of television itself. lan Kershaw writes that 'the lifeblood of a history seminar at a university is disagreement and problems of interpretation... [on television,] problems of interpretation tend to muddy the waters, and to leave the viewer confused, baffled, or at least unable to decide which of variant interpretations is the most valid. ${ }^{26}$ I was discouraged from presenting ambiguous interpretations in stories I worked on. But perhaps assuming that audiences can only absorb one view of a historical event underestimates them. It must be possible to present a range of interpretations. One way this could be done is through websites or DVDs, as Jeremy Issacs describes. He noted that the producers of CNN's Cold War series made available on their website the full text of all 550 interviews conducted for the series. ${ }^{27}$ But this is rare and still locates alternative perspectives outside the program itself. Rewind had a small website that contained program transcripts and a guestbook, where disgruntled viewers pointed out factual errors and they could voice alternative points of view, but this was all outside the program. 
So if television prefers simple narratives, and academic historians resist them, how can historians feed the enormous public appetite for stories of our past? I wonder if what much of what we do as historians now is, to a great extent, incompatible with what television demands? For example, Rewind made more than one story about searching for a particular shipwreck. A shipwreck search fits the program's investigation criteria more easily than asking, for example, why do we valorize the failed invasion of Turkey above all Australian military engagements? A shipwreck is a tangible object; it usually attracts a few obsessed boffins who are keen to track it down, and with any luck, there's the payoff of finding the ship at the end. But what does a shipwreck tell us about ourselves, our history and our nation? Can these questions be presented in television history in a complex way? How can we create historical television that historians might want to watch, and should we? Mainstream media relies on the straight narrative with a Truth (with a capital ' $T$ ') while as John Cook notes: 'in the academic world, many in the humanities are arguably still wandering perplexed through the labyrinth of post-modernism, with its explicit disavowal of all forms of linear "grand narrative", including the very process of constructing and interpreting history. And it may well be, having found their way in to this maze that deliberately refused to possibility of any coherent exit points, few truly want to leave. ${ }^{28}$

Historians need to venture out of the maze occasionally and attempt to take history to a wide audience. The history wars have left historians and history vulnerable, and we need to get our voices and our work out there, divorced from an adversarial agenda. There is an enormous public hunger for historical stories, and Rewind is just one imperfect way to feed that hunger. At my most optimistic, I believe that television history is a way to communicate between universities and the public, to whet a popular appetite for history, and perhaps, even to lure students into the lecture theatres and bookshops after their interest has been stimulated to find out more, to explore the past in all its complexity. Hunt writes: 'In its more admirable manifestations, television history could be regarded as part of the process of bridging the gulf: ensuring the achievements of an all too often introverted academe receive public acknowledgement and an appreciation of their relevance. And it is an increasingly important task in a diminishing public sphere with universities under ever greater pressure to justify their resources. ${ }^{29}$ $\mathrm{He}$ is right. And it means that historians need to be more skilful and savvy in their use of the media. As someone who is trying to do just that, I believe that historians should take their work out of the academy and get their hands a little dirty - but I would say that, wouldn't I?

\section{ENDNOTES}

1 'Liz' on the Rewind guestbook commented: 'Wow, this show is great! I'm a history major and I've decided that I want to be a TV historian when I grow up!',

http://www2b.abc.net.au/guestbookcentral/list.asp?guestbookID=207, Accessed 13 October 2004. 
2 Paul Ashton and Paula Hamilton, 'At Home with the Past: Background and Initial Findings from the National Survey', in Paula Hamilton and Paul Ashton (eds), Australians and the Past: A National Survey, special issue of Australian Cultural History, vol 22, 2003, p11.

3 David Cannadine, 'Introduction', History and the Media, Palgrave Macmillan, London, 2003, p4.

4 ibid.

5 Simon Schama, 'Television and the Trouble with History', in Cannadine, op cit, p20.

6 Natalie Zemon-Davis, 'Any Resemblance to Persons Living or Dead: Film and the Challenge of Authenticity', The Yale Review, vol 76, no 4, 1987, pp457-82.

7 Ian Jarvie, 'Review Essay: History on Television', Historical Journal of Film, Radio and Television, vol 21, no 1, 2001, p99.

8 Cannadine, op cit, p4.

9 Sue Castrique, 'Beyond Text: Reflections on Historical Television', Public History Review, vol 9, 2001, p97.

10 Taylor Downing, 'History on Television: the making of "Cold War", 1998', Historical Journal of Film, Radio and Television, vol 18, no 3, 1998, pp325-333.

11 Taylor Downing, 'Bringing the Past to the Small Screen', in Cannadine, op cit, p7. 12 ibid, p15.

13 Tony Moore, 'Cultural Cringe keeps our history out of the picture', Sydney Morning Herald, 19 August 2004, p13.

14 See, for example, Terry Television, 'How Aunty's History Detectives became Defective' 15 July 2004, www.crikey.com.au/media/2004/07/15-0002.print.html, accessed 15 July 2004 and 'Aunty gets set to Rewind', 30 July 2004, accessed 10 October 2004.

15 Schama, op cit, p 20.

16 Downing 'Bringing the Past to the Small Screen', op cit, p15.

17 Jarvie, op cit, p98.

18 Peter West, 'Sister Kenny', entry on Rewind guestbook, www2b.abc.net.au/guestbookcentral/list.asp?guestbookID=207, accessed 10 October 2004.

19 Sarah Masters, 'Sister Elizabeth Kenny', entry on Rewind guestbook, www2b.abc.net.au/guestbookcentral/list.asp?guestbookID=207, accessed 10 October 2004.

20 Cannadine, 'Introduction', op cit, p3.

21 lan Kershaw, 'The Past on the Box: Strengths and Weaknesses', in Cannadine, op cit, p122-3.

22 Stuart Macintyre and Anna Clark, The History Wars, Melbourne University Press, Melbourne, 2003, p12.

23 Ben Johnson, 'Scientist Backed Germ War', Sunday Telegraph, 8 August 2004, p35.

24 Robin Bromby, 'Toying with our past', The Weekend Australian, Review, 4-10 September 2004, p28.

25 Before the advent of an effective vaccine, polio was an unpredictable, devastating illness and, as Naomi Rogers notes, 'doctors were unable to predict, prevent or treat it, and victims were sometimes left crippled, sometimes miraculously unaffected.' I felt that Sister Kenny could possibly have been claiming credit for recoveries which would have happened anyway. Naomi Rogers, 'Sister Kenny Goes to Washington: An Unorthodox Nurse, Polio and Medical Politics in Postwar America', New York Academy of Medicine Seminar, February 29, 2000. http://cues.nyam.org/history/hist00_1.html, accessed 8 June 2004.

26 Kershaw, op cit, p121.

27 Jeremy Issacs, 'All Our Yesterdays', in Cannadine, op cit, p43.

28 John R. Cook, 'Review Essay: History Makers', Historical Journal of Film, Radio and Television, vol 22, no 3, 2002, p376.

29 Tristram Hunt, 'Hacks and Scholars: Allies of a Kind', in Cannadine, op cit, p96. 